\title{
Climate and land-use change impact on faecal indicator bacteria in a temperate maritime catchment (the River Conwy, Wales)
}

Bussi, Gianbussi; Whitehead, Paul; Thomas, Amy; Masante, Dario; Jones, Laurence; Cosby, Jack; Emmett, Bridget; Malham, Shelagh; Prudhomme, Christel; Prosser, Harvard

\section{Journal of Hydrology}

DOI:

10.1016/j.jhydrol.2017.08.011

Published: 01/10/2017

Peer reviewed version

Cyswllt i'r cyhoeddiad / Link to publication

Dyfyniad o'r fersiwn a gyhoeddwyd / Citation for published version (APA):

Bussi, G., Whitehead, P., Thomas, A., Masante, D., Jones, L., Cosby, J., Emmett, B., Malham, S., Prudhomme, C., \& Prosser, H. (2017). Climate and land-use change impact on faecal indicator bacteria in a temperate maritime catchment (the River Conwy, Wales). Journal of Hydrology, 553, 248-261. https://doi.org/10.1016/j.jhydrol.2017.08.011

\footnotetext{
Hawliau Cyffredinol / General rights

Copyright and moral rights for the publications made accessible in the public portal are retained by the authors and/or other copyright owners and it is a condition of accessing publications that users recognise and abide by the legal requirements associated with these rights.

- Users may download and print one copy of any publication from the public portal for the purpose of private study or research.

- You may not further distribute the material or use it for any profit-making activity or commercial gain

- You may freely distribute the URL identifying the publication in the public portal ?
}

Take down policy

If you believe that this document breaches copyright please contact us providing details, and we will remove access to the work immediately and investigate your claim. 


\section{Accepted Manuscript}

Research papers

Climate and land-use change impact on faecal indicator bacteria in a temperate maritime catchment (the River Conwy, Wales)

Gianbattista Bussi, Paul G. Whitehead, Amy R.C. Thomas, Dario Masante, Laurence Jones, B. Jack Cosby, Bridget A. Emmett, Shelagh K. Malham, Christel Prudhomme, Havard Prosser

PII: S0022-1694(17)30537-1

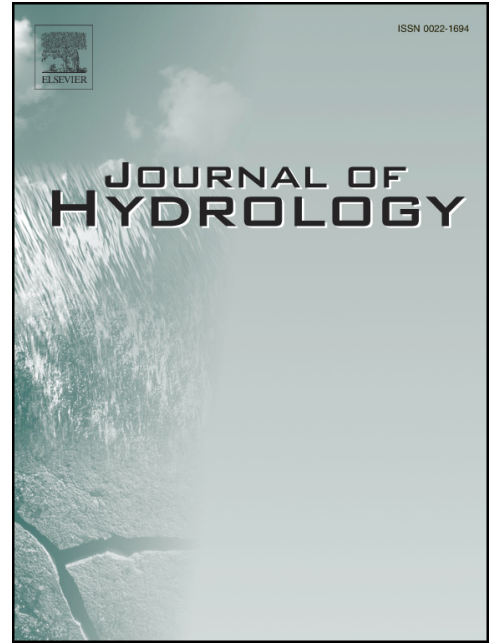

DOI:

Reference: http://dx.doi.org/10.1016/j.jhydrol.2017.08.011

To appear in: HYDROL 22174

Received Date: 9 January 2017

Revised Date:

2 August 2017

Accepted Date:

9 August 2017

Please cite this article as: Bussi, G., Whitehead, P.G., Thomas, A.R.C., Masante, D., Jones, L., Jack Cosby, B., Emmett, B.A., Malham, S.K., Prudhomme, C., Prosser, H., Climate and land-use change impact on faecal indicator bacteria in a temperate maritime catchment (the River Conwy, Wales), Journal of Hydrology (2017), doi: http:// dx.doi.org/10.1016/j.jhydrol.2017.08.011

This is a PDF file of an unedited manuscript that has been accepted for publication. As a service to our customers we are providing this early version of the manuscript. The manuscript will undergo copyediting, typesetting, and review of the resulting proof before it is published in its final form. Please note that during the production process errors may be discovered which could affect the content, and all legal disclaimers that apply to the journal pertain. 


\section{Climate and land-use change impact on faecal indicator bacteria in a temperate maritime catchment (the River Conwy, Wales)}

Gianbattista Bussi ${ }^{1 *}$, Paul G. Whitehead ${ }^{1}$, Amy R.C. Thomas ${ }^{2}$, Dario Masante ${ }^{2}$, Laurence Jones ${ }^{2}$, B. Jack Cosby ${ }^{2}$, Bridget A. Emmett ${ }^{2}$, Shelagh K. Malham ${ }^{3}$, Christel Prudhomme, ${ }^{4,5,6}$, Havard Prosser ${ }^{7}$

1 - School of Geography and the Environment, University of Oxford, South Parks Road, Oxford, OX1 3QY (UK)

2 - Centre for Ecology \& Hydrology (CEH), Environment Centre Wales, Deiniol Road, Bangor, Gwynedd, LL57 2UW (UK)

3 - School of Ocean Sciences, Bangor University, Menai Bridge, Anglesey, LL59 5AB (UK)

4 - European Centre for Medium-Range Weather Forecasts, Shinfield Park, Reading, RG2 9AX (UK)

5 - Department of Geography, Loughborough University, Loughborough, LE11 3TU (UK)

6 - Centre for Ecology and Hydrology (CEH), Benson Lane, Crowmarsh Gifford, Wallingford, OX10 8BB (UK)

7 - Cardiff School of Biosciences, Cardiff University, Museum Avenue, Cardiff, CF10 3AX (UK)

*Corresponding author: gianbattista.bussi@ouce.ox.ac.uk

\section{Abstract}

Water-borne pathogen contamination from untreated sewage effluent and runoff from farms is a serious threat to the use of river water for drinking and commercial purposes, such as downstream estuarine shellfish industries. In this study, the impact of climate change and land-use change on the presence of faecal indicator bacteria in freshwater was evaluated, through the use of a recentlydeveloped catchment-scale pathogen model. The River Conwy in Wales has been used as a case- 
study, because of the large presence of livestock in the catchment and the importance of the shellfish harvesting activities in its estuary. The INCA-Pathogens catchment model has been calibrated through the use of a Monte-Carlo-based technique, based on faecal indicator bacteria measurements, and then driven by an ensemble of climate projections obtained from the HadRM3-PPE model (Future Flow Climate) plus four land-use scenarios (current land use, managed ecosystem, abandonment and agricultural intensification). The results show that climate change is not expected to have a very large impact on average river flow, although it might alter its seasonality. The abundance of faecal indicator bacteria is expected to decrease in response to climate change, especially during the summer months, due to reduced precipitation, causing reduced runoff, and increased temperature, which enhances the bacterial die-off processes. Land-use change can also have a potentially large impact on pathogens. The "managed ecosystems" scenario proposed in this study can cause a reduction of $15 \%$ in average water faecal indicator bacteria and up to $30 \%$ in the $90^{\text {th }}$ percentile of water faecal indicator bacteria, mainly due to the conversion of pasture land into grassland and the expansion of forest land. This study provides an example of how to assess the impacts of human interventions on the landscape, and what may be the extent of their effects, for other catchments where the human use of the natural resources in the uplands can jeopardise the use of natural resources downstream.

Keywords: Pathogens; Water quality modelling; River Conwy; Climate change; Land-use change

\section{Introduction}

Anthropogenic activities such as farming and livestock management or sewage discharges can cause pollution by faecal bacteria and pathogenic viruses in rivers (Malham et al., 2014). This type of pollution can pose both serious health threats and affect the use of water by humans, such as commercial activities (for example, shellfish growth in river estuaries) or recreational activities, with severe social and economic consequences. This has already occurred in many regions of the world, such as the decline of marine water quality in Western Africa (Bouvy et al., 2008), the degradation of coral reef in the Caribbean (Hernández-Delgado et al., 2008)and the contamination of drinking water in Brazilian shanty towns (Copeland et al., 2009) with global impacts on the recreational use of water (WHO, 2003). Faecal Indicator Bacteria (FIB), such as total coliforms or faecal coliforms, are used to 
detect and measure faecal contamination in water and sediment, and are a widespread indicator of the presence of pathogen organisms in freshwater or brackish water.

Whilst there is a growing body of research outcomes concerning the sources, sinks and transport of FIB in freshwater and estuarine environments (Perkins et al., 2016), in river sediment (Perkins et al. 2014), in sewage water (Kay et al., 2008) and groundwater (Kay et al., 2007), these approaches might be limited for the analysis of the dynamic response of FIB to changes in climate and land use/land management (Whitehead et al., 2016). To understand land-use, climate change, and population growth impacts on FIB, mathematical models are required to describe point and diffuse FIB sources and transport at the catchment scale. Models can be used to develop informed health risk assessments and evaluate policy reforms and land-use change options (Whitehead et al., 2016), taking into account the joint impact of climate and land-use change (Bussi et al., 2016a).

In particular, physically-based models, or mechanistic modes (de Brauwere et al., 2014), combined with direct FIB measurements, can provide daily estimates of FIB in rivers in response to climatic events. An example is the INCA-Pathogens model (Whitehead et al., 2016), which belongs to the INCA family of models (Whitehead et al., 1998b), and can be used to simulate the cycle of FIB in a catchment, taking into account both diffuse and point sources and the decay from sources to sinks. However, the use of physically-based models is limited by the lack of data. Usually, FIB data are intermittent, with low collection frequencies (weeks to months) and short time coverage. Therefore, robust modelling approaches are needed to tackle this problem, taking into account the different sources of uncertainty (data, model structure, model parameters, etc.).

In this study, the INCA-Pathogens model was used to understand the impacts of upland faecal pollution on the downstream concentration of FIB under a changing climate and under several scenarios of land use and land management. The model was calibrated against observed FIB data (Emmett et al., 2016) using a Monte Carlo procedure, and then coupled with climatic projections (Prudhomme et al., 2012) and land-use scenarios (Prosser et al., 2014). The model parametric uncertainty of the climatic model and the pathogens model were also taken into account. The model results were used to estimate the consequences of upland pollution on the flux of FIB into the river estuary and to gain knowledge regarding the possible measures to mitigate it by acting on the upland landscape and land cover. In particular, the objectives of this study are: (i) to assess the fate of 
pathogen contamination from upland livestock activity in terms of river water quality; (ii) to investigate and quantify the impact of landscape management on the mitigation of faecal pollution; and (iii) to provide a methodological framework to analyse the impact of faecal pollution under a changing climate and land use.

\section{Study area}

The River Conwy catchment is located in the north-west of Wales (UK) and is the third largest river discharging into the Irish Sea along the North Wales coast. It drains a catchment of $678 \mathrm{~km}^{2}$, with the main drainage channel covering a distance of $55 \mathrm{~km}$ (Figure 1). The upper reaches of the river cross upland blanket bog and moorland (Smith et al., 2007), passing through improved grazing land and conifer plantations via steep gorges to the town of Betws-y-Coed (reach 4 in Figure 1). The lower Conwy, which flows through extensive flood plains and by several larger towns, meets the tidal limit downstream reach 5 (Figure 1), around $20 \mathrm{~km}$ inland from the estuary mouth. Three major tributaries (the Machno, Lledr and Llugwy) join the upper Conwy from the west, and drain many of the high mountains of the Snowdonia National Park (elevation up to $1086 \mathrm{~m}$ a.s.l.). More information regarding the catchment can be found in Perkins et al. (2014).

There is a marked precipitation gradient from the lowlands (valley bottom and Eastern part of the catchment) to the highlands (Western part of the catchment). The mean annual precipitation is typically slightly below $1000 \mathrm{~mm}$ in the lowland and it exceeds the $3000 \mathrm{~mm}$ on the highest peak, for example on the mount Snowdon.

The catchment contains many important conservation sites. The western and southern parts of the catchment fall within the Snowdonia National Park. Thin soils, steep topographic gradients, impermeable rock and high rainfall lead to a rapid hydrological response. Mean annual runoff at the

Cwm Llanerch gauging station, above the tidal limit, is $19 \mathrm{~m}^{3} \mathrm{~s}^{-1}\left(1.74 \mathrm{~m} \mathrm{yr}^{-1}\right)$, with a mean annual flood of $376 \mathrm{~m}^{3} \mathrm{~s}^{-1}$. Historically this has caused frequent inundation of the floodplain and its villages and towns.

[Figure 1 here] 
The catchment is predominantly rural, with sheep farming as the main land use to the west and mixed dairy, beef and sheep farming to the east (Smith et al., 2007; Statistics for Wales, 2015). The lowland flood plain area, downstream of Betws-y-Coed, has some arable farming which requires improved drainage. To the west of Betws-y-Coed there is a large afforested area, the Gwydir Forest. The upper catchment is given over mainly to sheep farming. There is extensive semi-natural woodland cover in most sub-catchments including important areas of wet woodland (Smith et al., 2007; Statistics for Wales, 2015). The catchment landscape is of exceptionally high aesthetic quality, and tourism is the main contributor to the local economy (Conwy County Borough, 2017). Livestock farming and forestry management maintain the landscape quality as well as being productive in their own right.

There are a range of water quality and flow issues in the catchment requiring management including coastal pollution with microbial and viral pathogens, affecting shellfish in the estuary (Perkins et al., 2016, 2014). Consistent production of a good quality product is essential for a successful shellfish business. In the Conwy catchment the problem of increased microbial loadings on shellfish beds can affect the production of a consistently high quality product. Microbial pollution has also forced the failure of blue flag bathing beaches in the past. The closure of the fishery along with the loss of tourist income due to the closure of the blue flag beaches would cause not only a direct loss to the local economy, but also large indirect economic losses.

\section{Methodology}

\subsection{Faecal Indicator Bacteria data}

Freshwater samples were collected from several locations throughout the River Conwy catchment (Figure 1). As detailed in Perkins et al. (2014)and Emmett et al. (2016), samples were mixed and homogenised by shaking. Briefly water samples were processed within 4 hours of collection in accordance with the Revised Bathing Water Directive (2006/7/8EC) (Perkins et al 2014). Bacteria were enumerated following vacuum-filtration of the water sample through a $0.2 \mu \mathrm{m}$ cellulose acetate membrane filter. The membranes were transferred onto sterile agar plates containing selective medium for the numeration of E. coli and coliforms (Harlequin (LabM HAL008)). Agar plates were incubated and enumerated $24 \mathrm{~h}$ post incubation (Perkins et al., 2014) 
Sediment samples were assessed for coliforms and, briefly, E. coli by the transfer of $1 \mathrm{~g}$ of sediment to a $7 \mathrm{ml}$ sterile bijou tube and vortexed in Ringers solution to disassociate and resuspend the bacteria from the sediment (Perkins et al., 2014). Aliquots of the supernatant were aseptically transferred onto agar plates containing selective media for E. coli and total coliforms (Harlequin (LabM HAL008)). Bacteria colonies were enumerated following $2 \mathrm{~h}$ hours incubation.

The data used in the INCA model set-up are summarised in Table 1. The frequency of collection spans between 10 days and a month. The count of FIB can vary considerably within the same day. This is an important issue to take into account, since in this study a FIB model was set up at a daily scale, and its results are daily averages of FIB. To characterise the sub-daily variability of the FIB, several samples were collected every few hours within the same day. Figure 2 shows the sub-daily variation of the FIB for two sub-catchments.

[Table 1 here]

[Figure 2 here]

\subsection{The INCA-pathogens model}

The INCA model is a semi-distributed process-based model developed to simulate the transfer of pollutants from the landscape and point sources to the river. It was originally developed to estimate the concentration of nitrogen (Wade et al., 2002a; Whitehead et al., 1998a) and phosphorus (Wade et al., 2002b) in rivers. Many modules have been added to the main model during the last decade, including carbon (Futter et al., 2007), sediment (Lázár et al., 2010), organic contaminants (Lu et al., 2016) and microplastics (Nizzetto et al., 2016). One of the most recent development of the INCA model is the pathogens module (Rankinen et al., 2016; Whitehead et al., 2016).

There are many approaches to modelling pathogen organisms (de Brauwere et al., 2014). Some recent approaches include export coefficient and regression analysis (Kay et al., 2008; McGrane et al., 2014). These approaches are often used where data is limited or where broad policy advice is required. Chapra (2013) reports a process-based approach taking into account the growth and die-off dynamics of pathogens. This approach forms the basis of most stream models (Coffey et al., 2013; 
Ferguson et al., 2007; ludicello and Chin, 2015) and has been extended to include terrestrial components as part of the Soil and Water Assessment Tool (SWAT) applied to whole catchments (Coffey et al., 2013). Risk based approaches have also been used in literature (Muirhead et al., 2011).

Nevertheless, these approaches are often uncertain, unlinked from the underlying hydrology, or focusing on only a single part of the environmental cycle of FIB. INCA provides an integrated platform. In addition, the hydrological and sediment sub-models of INCA have already been tested repeatedly in literature.

The hydrological sub-model of INCA simulates the transformation of rainfall into runoff and the propagation of water through a river network (Wade et al., 2002a). Its inputs are daily time series of precipitation, temperature, hydrologically effective rainfall, and soil moisture deficit. The latter two are estimated using another semi-distributed hydrological model, called PERSiST (Futter et al., 2014). PERSiST is a semi-distributed physically-based catchment-scale rainfall-runoff model which is specifically designed to provide input series for the INCA family of models. It is based on a userspecified number of linear reservoirs which can be used to represent different hydrological processes, such as snow melting, direct runoff generation, soil storage, aquifer storage and stream network movement. It is driven by daily precipitation and temperature, and it computes evapotranspiration in a manner similar to that presented by Durand (2004), but, instead of using Penman potential ET as the baseline, a degree day evapotranspiration parameter is used which defines the maximum (i.e. potential) evapotranspiration when air temperatures are above the growing degree day threshold. The PERSiST model has been tested over a variety of catchments, and in particular on several temperate catchments (Couture et al., 2014; de Wit et al., 2016; Oni et al., 2015, 2014; Whitehead et al., 2015b). The model was calibrated and validated against observed flows, obtaining a validation Nash and Sutcliffe index of 0.75 over a 26 year time slice.

The INCA-Pathogens model is capable of modelling the sources and sinks of pathogens and to capture the dominant dynamics and processes controlling pathogens in catchments. The model reproduces the storage of pathogens in soils, river water column, river sediments and groundwater, taking into account both diffuse inputs of pathogens from agriculture, urban areas or atmospheric deposition, and point source discharges from intensive livestock units or from sewage treatment 
works or any industrial input to river systems (Whitehead et al., 2016). The INCA model reproduces the processes of growth and die-off of the microorganisms in the soil and groundwater zones, taking into account the effect of temperature and solar radiation. The model can be used to reproduce any kind of pathogen microorganism, although, given the data availability, in this study it was used to simulate FIB as a proxy measure of faecal contamination of water.

\subsection{Model set-up and general sensitivity analysis}

HER and SMD were produced using the model PERSiST (Futter et al., 2014). Precipitation and temperature data were taken from Met Office stations. Several stations exist within the Conwy catchment, measuring daily precipitation, minimum temperature and maximum temperature among other variables. The INCA model requires a single series of daily precipitation and a single series of mean daily temperature. Given the topography of the catchment, with steep slopes and relatively large difference in elevation from the uplands to the lowlands, and the natural spatial variability of rainfall, a single station cannot provide exhaustive information about the precipitation falling on the catchment. For this reason, the spatial average of daily precipitation was determined using information from several raingauges spread all over the catchment (Table 2). For the temperature, the station 1171 was used, given that it has a long and uninterrupted record of maximum and minimum temperature. The mean daily temperature was calculated as the average between minimum and maximum daily temperature.

[Table 2 here]

Spatially distributed information is needed to estimate some of the INCA model parameters. The Ordnance Survey (OS) Terrain 50 was used as a digital elevation model (50 m horizontal resolution and $1 \mathrm{~m}$ vertical resolution). The digital elevation model was used to define the sub-catchment boundaries, to calculate the area of the sub-catchments and to compute mean sub-catchment and reach slope. The proportion of land use for each sub-catchment is required by the INCA model. The River Conwy catchment was divided into several sub-catchments (Table 3). For each catchment, properties such as catchment area, reach length and land uses were defined.

[Table 3 here] 
A general sensitivity analysis was applied to the INCA model of the River Conwy (Spear and Hornberger, 1980; Whitehead et al., 2015a). The following parameters were selected as the most influential and the sensitivity of the model results to them was analysed: (1) direct runoff, (2) soil water and (3) ground water residence times, (4) rainfall excess proportion, (5) maximum infiltration rate, (6) flow-velocity coefficient, (7) flow threshold for saturation excess direct runoff, die-off coefficient in soils $\left(\mathrm{C}_{3}\right),(8)$ animal addition rate, (9) manure addition rate, (10) manure addition period, (11) die-off coefficient in groundwater $\left(C_{5}\right)$, (12) flow discharged as effluent, (13) FIB addition rate from effluents, (14) decay coefficient in water $\left(C_{7}\right),(15)$ deposition rate $\left(C_{8}\right),(16)$ shear velocity threshold, (17) resuspension rate $\left(C_{9}\right)$ and (18) decay coefficient in sediment $\left(C_{11}\right)$. The ranges of variation of the model parameters were also based on previous studies (Bussi et al., 2017, 2016a; Jackson-Blake and Starrfelt, 2015), although they were kept reasonably broad. The feasible space of model parameters was sampled randomly, and 10,000 different parameter sets were generated. Subsequently, the INCA model was run with each of these parameter sets, and its performance was assessed based on observed values of flow and sediment at reach 4, using data from 2013 to 2014 . The metric used for model assessment was the Nash and Sutcliffe Efficiency (NSE - Nash and Sutcliffe, 1970). Thresholds of NSE values were used to split the 10,000 parameter sets into behavioural and non-behavioural (Spear and Hornberger, 1980). In particular, a threshold of 0.5 for the flow and a threshold of 0.15 for the total coliform abundance were used. Following the model evaluation guidelines of Moriasi et al. (2007), the flow threshold corresponds to a "good" model performance. The 21 selected behavioural models were used in the rest of the study, providing ensemble results of flow and total coliforms.

\subsection{Climate scenarios}

In this study, the Future Flow Climate (FFC) product was employed with the aim of assessing the impact of climate change on the flow and FIB of the River Conwy. FFC (Prudhomme et al., 2012) is a consistent set of climate change projections for the whole of Great Britain at both space and time resolutions appropriate for hydrological applications. It enables climate change uncertainty and climate variability to be accounted for in the assessment of their possible impacts on the environment. It is based on the Hadley Centre's 11-member ensemble projections HadRM3-PPE run under the Medium emission scenario SRES A1B. The 11 plausible realisations (all equally likely) of nearly 150 
years (from 1951 to 2098) enable the role of climate variability on river flow and groundwater levels nationally to be investigated and how this may change in the future. Some climate change uncertainty is accounted for by considering all ensemble members together (Murphy et al., 2009). FFC includes bias-corrected and downscaled projections of precipitation and evapotranspiration; in addition, temperature data can be made available on demand. It corresponds to an 11-member ensemble of transient projections from January 1950 to December 2098, for historical and SRES A1B emissions scenarios (Nakicenovic et al., 2003), each a single realisation from a different variant of HadRM3. Data are provided on a 1-km grid over the HadRM3 land areas. In this study, the INCA model was run using each of the 11 members as input. The same product was used to produce the Future Flows Hydrology, i.e. an ensemble of daily river flow to be used for climate change impact assessment across Great Britain (Prudhomme et al., 2013). No further bias correction was carried out on the FFC, which underwent such a procedure during its development (see Prudhomme et al., 2012).

[Figure 3 here]

Figure 3 shows the monthly averages of precipitation and temperature for the River Conwy catchment for the control period (1960-1990) and for two future time periods (2020-2050 and 2060-2090). Precipitation is projected to decrease slightly in summer and increase slightly in winter. However, if the climate model uncertainty, given by the 11 climate model members which define the solid area in Figure 3, is taken into account, no clear signal of increase or decrease can be devised. On the other hand, temperature is clearly projected to increase, both in summer and in winter, by around $1.7^{\circ} \mathrm{C}$ and $3.2^{\circ} \mathrm{C}$ for the time periods $2020-2050$ and $2060-2090$ respectively.

\subsection{Land-use scenarios}

Four land use scenarios were employed in this study. The first scenario, or baseline, represents the current land use. The Land Cover Map 2007, released by the Centre of Ecology and Hydrology in 2011, was used to characterise the land uses in the catchment (Smith et al., 2007). The land cover categories were aggregated to six classes of land use: Urban, Forest, Natural Grassland, Improved grassland, Shrubland and Arable.

Other three scenarios were considered in this study. These land-use scenarios are part of the DURESS (Diversity of Upland Rivers for Ecosystem Service Sustainability) project, launched in May 
2012 (Prosser et al., 2014). The DURESS scenarios resulted from appraising drivers of change in an expert workshop representing all appropriate sectors (farming, forestry, water, nature, communities), identifying plausible land management responses to each driver of change, called projections, analysing possible interplay among these projections to construct different storylines.

One of these storylines is the managed ecosystems scenario, where ecosystem integrity is proactively enhanced to safeguard water, carbon and nature through either public funding of agrienvironment schemes or because the market value of these services increases. Carbon and biodiversity management becomes the dominant management paradigm in upland systems. Policy is focused on restoring peatlands, and expanding wetlands and woodland to increase biomass and regulate soil carbon exports. Reliance on overseas areas for provisioning services (fuel, fibre and food) may increase.

The second scenario considered is the agricultural abandonment. In this storyline, land becomes abandoned as a result of market or regulatory failure of the other three scenarios, leading to rapid decline in production and unmanaged development of quasi-natural habitats. In particular, existing upland policies become too costly to implement because of competition for public funds for other priorities, and lack of viable markets for products and services. Sustainability of farming enterprises becomes compromised through loss of farm succession and poor uptake of new technology and practices. Decline in farming activity and upland livelihood opportunities leads to eventual abandonment. Upland communities become more dependent on external jobs, with takeover for retirement and tourism.

The third scenario is the agricultural intensification. In this storyline, maximising food and fibre production becomes crucial to meet the challenges of food security and increasing global demand. Global food security forces policy to focus on production: Hill farming is now expected to be an important contributor to the national livestock industry by providing breeding and finishing stock to lowland farming systems and fatstock for the market. Environmental protection activity is limited to compliance with regulations.

Based on these considerations, land use maps were developed, corresponding to the four scenarios described above, and then reclassified following the land-use categories shown in Table 3Error! Reference source not found.. As part of the scenarios development, the direction of change for 
each land use type was established. A suitability model was built for all land classes predicted to change, based on spatially sensitive drivers of change. In particular, land cover data, agricultural data, farming statistics, elevation data and rivers and road maps were used to establish the most suitable area for every land use, depending on the scenarios. Change was then allocated spatially according to the amount dictated by projections, starting from the most suitable polygons in the current land cover map. The scenarios were considered as static, i.e. they did not change in response to changes in the climate (Bussi et al., 2017). The results can be seen in Figure 4, where four of the six land use categories are shown for the four land-use scenarios considered in this study.

[Figure 4 here]

\section{Results}

\subsection{Model calibration}

The results of the selected behavioural models from the Monte Carlo General Sensitivity Analysis are shown in Figure 5 for Reach 4 (Cwn Llanerch). It can be seen that the model performance in reproducing the observed flow is very good. On the other hand, the spread of the model results for FIB in water and FIB in sediment is quite wide, although the observed values (black dots) are predominantly contained within the model result area, indicating that, given the observations available, the model is providing a good performance.

The model spatial validation is shown in Table 4. In this table, the correlation coefficients $\left(R^{2}\right)$ of the median of the model results with the observations are shown for all the reaches with data available, for flow, FIB in water and FIB in sediment.

[Table 4 here]

[Figure 5 here]

Given that the aim of this model implementation is not FIB forecasting day-by-day FIB count reproduction, but rather understanding the response of FIB to climate and land-use variations at the catchment scale, the model validation can be carried out in terms of the distribution of the observed and simulated values of FIB, rather than by comparing the daily time series. For this reason, the 
empirical cumulative distribution function of the observed data and the model results were computed (Figure 6). Note that the model results were resampled with the same time frequency as the observed values (e.g. monthly) for consistency, similarly to Bussi et al. (2016a). It can be seen that, in general, the distribution functions of the observed values (black lines) lie within the area defined by the distribution function of the simulated values (grey areas) for all the stations, especially for values with probability larger than 0.5 . It can be seen that the observed distribution functions often start from the left part of the plot, while the simulated distribution functions do not reproduce this behaviour. This means that values of FIB $=0 \mathrm{CFU} 100 \mathrm{~mL}^{-1}$ were measured. In these cases, it might be that the count of FIB was below the limit of detectability, and therefore it was classified as 0 . It is important to note, however, that the $x$-axis are logarithmic, and the differences between observed and simulated values in the left part of a plot is much smaller than the differences between observed and simulated values in the right part.

[Figure 6 here]

Given that the model was used to simulate the time period 1960-1990, a retrospective validation is also provided here. In Figure 7, the model validation the time period 1960-1990 is shown. These results were obtained by running the INCA model driven by measured precipitation and temperature, and then compared with water flow observations at the station of Cwm Llanerch (reach 4), available starting from 1964. In this model validation run, the land use was considered unchanged, due to lack of data, even though changes occurred in such a long time period. Furthermore, the quality of the historical data required for both the input information (precipitation and temperature) and the flow observations was variable and sometimes not ideal. Despite that, the model obtained an overall good performance, with NSE values ranging between 0.48 and 0.65 , depending on the behavioural model parameterisation.

[Figure 7 here]

No retrospective data were available to validate the FIB results of the INCA model. This should not affect the validity of the results of this paper for the following reasons: (i) the modelling strategy employed in this paper, including a general sensitivity analysis and the selection of behavioural models, allows taking into account the large uncertainty of the model results; (ii) the model results in terms of FIB for the scenarios are in the range of available data at the calibration stage (2013-2014), 
indicating that the model results are not extrapolated from the domain they were calibrated on, and hence still reliable.; (iii) the model is not used as a forecast model, but just to assess the impact of land-use change and climate change on FIB, i.e. to detect trends and changes due to external drivers, averaged over long time periods; and (iv) the relative changes in flow and FIB concentration are reported and discussed, rather than the absolute values, thus reducing the model bias (potentially even removing the bias, if one assumes that the model bias is additive and remains the same under current and future conditions, although this hypothesis cannot be tested for obvious reasons). Therefore, for the purposes of this study, the model has been validated and can be used for guiding policy making, within the limitations that have been discussed in the manuscript.

\subsection{Climate change impact}

The response of the River Conwy to climatic changes at reach 4 is shown in Figure 8 . The response in terms of flow, FIB in water and FIB in sediment is represented as monthly average values (Figure 8a, $c$ and e) and as distribution functions (Figure $8 \mathrm{~b}, \mathrm{~d}$ and f). It can be observed that no major changes are expected to affect the hydrological regime of the River Conwy on the short term (20202050), in accordance with the forecasted changes in precipitation (Figure 3). Nevertheless, the width of the area defined by the monthly flow values for the 2020-2050 time period is in general wider than the area defined by the monthly flow values for the 1960-1990 period, indicating that the uncertainty on the future climate estimated by the FFC product is larger than the variability of the current climate. Concerning the 2060-2090 temporal period, it can be noticed that a decrease in summer flows is forecasted, as well as a general decrease in flows with a non-exceedance probability between 0.1 and 0.4. This is mainly due to the increase in temperature and decrease in summer temperature forecasted by the FCC model (Figure 3). At the same time, an increase in winter flow is also shown in Figure 8. In numerical terms, the average flow is not expected to change greatly for reach $4(+2.5 \%$ for the $2020-2050$ period and $+2.7 \%$ for the $2060-2090$ period in average), but the seasonality of the flow is projected to change. Winter flows (DJF) are projected to increase by $4.3 \%$ for the $2020-2050$ years and by $13.1 \%$ for the $2060-2090$ years, while summer flows (JJA) are expected to decrease by $5.2 \%$ and $25.1 \%$ respectively. These increased flows will effectively dilute the FIB discharges entering the river system, if the sources of FIB are unchanged (this will probably be the case for point sources, but it is unlikely to be true for diffuse sources). 
[Figure 8 here]

The impact of climate change on FIB in water and sediment can also be seen in Figure 9. There is a clear signal of reduction of FIB in the Conwy catchment, especially for the summer months. Average reduction is $17 \%$ for $2020-2050$ and $29 \%$ for $2060-2090$, with a reduction for the summer months of $16 \%$ and $31 \%$ respectively. Similar figures describe the impact of climate change on FIB in sediment: average decreases of $18 \%$ and $31 \%$, and summer decreases of $16 \%$ and $33 \%$ for $2020-2050$ and for 2060-2090 respectively. Climate change seems to have also a similar impact on high FIB concentrations: the reduction on FIB concentrations with a non-exceedance probability larger than 0.9 is $14 \%$ and $-26 \%$ for $2020-2050$ and for $2060-2090$ respectively.

\subsection{Land-use change impact}

The results of the joint assessment of climate and land-use change on the FIB in the River Conwy (reach 4) are shown in Figure 9. These plots show the monthly averages of FIB in water and the distribution functions of FIB in water under the four land-use scenarios considered in this study (baseline and managed ecosystems) and at different time horizons (1960-1990, 2020-2050 and 20602090). It can be noticed that the abandonment scenario causes a general decrease in FIB, which is especially noticeable during the summer months. The managed ecosystems scenario also causes a decrease in summer FIB, with an effect similar to the abandonment scenario. The intensification scenario causes a sharp increase in summer FIB, leading to a concentration that is around double that of the managed ecosystem scenario.

The same results can be seen in Table 5, for the reaches 4,16 and 18, where the change of FIB in water is shown for all the combinations of land-use scenario and time horizon, both in terms of median changes and changes in the $90^{\text {th }}$ percentile of FIB (i.e., high abundance of FIB). It can be seen that climate change is responsible for a reduction of around 15\% in FIB by $2020-2050$ and a further $15 \%$ by $2060-2090$. The managed ecosystem scenario can reduce the median concentration of FIB by $10 \%$ to $24 \%$, depending on the sub-catchment and the time period, while the abandonment scenario can reduce it by up to $37 \%$ and the intensification scenario can cause an increase in FIB of $37-65 \%$.

[Figure 9 here] 
From Table 5, it is interesting to note that the land-use scenarios have different impacts depending on the sub-catchment. For example, the abandonment scenario does not seem to have a very large impact for sub-catchment 18 (15\% reduction of FIB under $1960-1990$ climatic conditions), which is a montane catchment, but it has a substantial impact on sub-catchment 16 (46\% reduction of FIB under 1960-1990 climatic conditions), which is an upland pasture sub-catchment, and on the whole of the Conwy catchment at reach 4 (46\% reduction of FIB under 1960-1990 climatic conditions). Furthermore, it can be noticed that the joint impact of climate and land use has a non-linear effect on the distribution of FIB. For example, while the median FIB reduction caused by the managed ecosystem scenario under $2060-2090$ climatic conditions at reach 4 is $46 \%$, the reduction in the $90^{\text {th }}$ percentile of $\mathrm{FIB}$ is $58 \%$, under the same climatic conditions.

[Table 5 here]

\section{Discussion}

Several sources of uncertainty affect the results of the INCA-Pathogens model. First of all, the FIB model used in this study was calibrated based on instantaneous intermittent data. These data are certainly affected by measurement uncertainty and by the natural sub-daily variability, which is shown in Figure 2. This is likely to affect the model ability to reproduce the catchment processes. Thus, it is important to highlight that more data is needed to understand FIBs movement in rivers and model their behaviour. Second, the sources of FIBs within the catchment are also uncertain. A better appraisal of the farming and livestock activities within the catchment is needed to strengthen the results of this study. Third, INCA-Pathogens is, as all models, a simplification of the reality, and therefore its results are affected by structural errors which must be considered. In this paper, a Monte Carlo-based technique to assess the model error and take into account the parametric uncertainty of the model was employed to overcome this limitation, although the results show a rather large spread of behaviours, which can only be reduced by addressing all the limitations listed above.

The climate scenarios adopted in this study enable the climate model parameter uncertainty and climate variability to be accounted for (Prudhomme et al., 2012), through the use of 11 different perturbations of the atmospheric parameterisation of a climate model (Murphy et al., 2009). In particular, the INCA model was driven by 11 different realisation of a climate model, thus 
incorporating the climate model parametric uncertainty. In a similar way, the general sensitivity analysis adopted and the use of several behavioural models allows estimating the parameter uncertainty of the hydrological and FIB model, by sampling different equifinal parameterisations (Spear and Hornberger, 1980). Furthermore, it allows calibrating the model in a robust and objective way, overcoming the equifinality problem (Beven, 1989). However, the resulting FIB model result interval is quite broad, indicating that the uncertainty in the model results is very high. This is due to the model structure, which is obviously a simplification of the real system, to uncertainty in the quantification of the input parameters and variables (e.g., the use of manure, the presence of livestock, the spatial variation of precipitation, etc.) but also because of the scarcity of data and the uncertainty of the measurements. Given the data and tools available, the results provided by coupling INCA-Pathogens and the FFC scenarios appears to provide robust and reliable results, which take into account the different sources of uncertainty, and can be used to inform decision making and land management.

The climate change impact on flow is expected to follow the pattern of wetter winters and drier summers that has been noted elsewhere in Britain (Whitehead et al., 2009), although no large changes are expected in the short term. This is shown in Figure 3, although it can also be seen that not all scenarios indicate this pattern. Some of them show wetter winters and wetter summers. The main drivers of change are temperature, which drives evapotranspiration, and precipitation, which drives changes in runoff. Temperature is expected to rise, thus leading to drier soils and therefore reduced flows, while precipitation should increase in winter and decrease in summer, with proportional effects on the river flow.

Concerning climate change impacts on FIB, these have been mainly linked to changes in precipitation. Half of the waterborne disease outbreaks in the US during the last half century followed a period of extreme rainfall (Delpla et al., 2009; Hunter, 2003). Heavy rainfall may wash pathogens from soils and lead to changes in the direction of flow of water systems. Heavy rainfall can also lead to overflow of storm drains that may be combined with the sewage system, mixing faecally polluted water with river water. Surface water turbidity can also increase during heavy rainfall events (Hunter, 2003). For example, heavy rains following a period of drought coincided with a major outbreak event of E. coli in New York (US) in 1999. The likelihood of phenomena may be increased by high soil 
saturation, which enhances rapid transport of microbial organisms (Rose et al., 2001). Additionally, floods often lead groundwater contamination (Hunter, 2003).

In the case of the River Conwy, the opposite seems to take place: rainfall is not forecast to change in average, and is forecast to decrease in summer, especially for the 2060-2090 years (Figure 3). This leads to lower flows in summer, which in turn cause a decrease in FIB concentration in water and sediment, due to a decrease in the export of FIB from soils and the transport of FIB from sources to sink. However, attention should be paid to extreme events during colder seasons. The increase in winter precipitation forecasted by climate models could lead to increased flow and increased FIB concentration, although the model results suggest that summer events are responsible for a larger proportion of FIB transport.

Temperature also affects the spread of waterborne diseases, although a rise in global temperature is expected to increase the likelihood of other types of health threats, such as for example toxins derived from cyanobacteria (Bussi et al., 2016b; Hunter, 2003). It is also hypothesised that higher water temperatures will lead to a pathogen survival increase, although there is still no clear evidence (Hunter, 2003), and the INCA-Pathogens model does not take this phenomenon into account. On the other hand, an increase in temperature will increase the die-off of FIB in soils and will lead to longer residence times in the river channels, thus causing a decrease in FIB. For example, Garzio-Hadzick et al. (2010) quantified with laboratory experiments the relationship between temperature and $E$. coli die-off, and an exponential relationship is widely adopted to describe this phenomenon (Chick, 1908).

As previously shown for example by Tong and Chen (2002), the impact of land use change on water quality can be assessed through the use of modelling tools like the INCA-Pathogens model (Whitehead et al., 2016). The results of this study show that a substantial reduction of FIB in water can be achieved by implementing the managed ecosystems scenario. This reduction is around $15 \%$ in terms of average FIB and can be up to $30 \%$ for high concentrations of FIB. This is mainly attributable to the conversion of pasture to grassland, thus reducing the sources of pathogens in the River Conwy catchment (mainly located within the pasture areas), and to the expansion of forest land, which reduces soil erosion and sediment transport (Buendia et al., 2016) and therefore reduces the abundance of FIB attached to the river bed sediment. The land-use scenarios considered in this study are static, i.e. they do not change along with changes in climate. This can be a limitation of the results 
here proposed, since it has been shown that considering land-use as a dynamical variable which responds to climate change can lead to different results (Bussi et al., 2017). This factor is to be taken into account in future developments of this study.

While the model results averaged over long time slices can identify some clear pattern of FIB variation (e.g. decrease of FIB in summer), they can also provide very useful information about the changes in the extremes. Table 5 also reports the intervals of variation (minimum/maximum). These results substantially follow the patterns indicated by the corresponding average values, but they also offer interesting insights. For example, it can be seen that, although a decrease in FIB due to less rainfall in summer is likely to happen, under some scenarios this decrease could be less pronounced that what the average model result suggests. In some cases, such as in the case of the intensification scenario at reach 16 , the maximum boundary of the range of variation is indicating a positive change $(+16 \%)$, while the average indicates a negative change $(-1 \%)$. Nevertheless, the confidence intervals showed in Table 5 generally corroborates the patterns detected by the average values, thus showing that the results of this study are robust.

\section{Conclusion}

This paper shows how faecal pollution might vary due to natural and anthropogenic stressors in a temperate catchment where the local economy has strong ties with the quality of water in the river mouth. In particular:

- Climate change is expected to decrease slightly the pathogens concentration and load in the river due to increased die-off rates caused by warming, and to lower flows.

Land use can alter significantly the pathogen cycle, leaving room for substantial reduction of faecal pollution by acting on the landscape through conversion of pastureland to grassland and the expansion of forest land.

This paper also provides a methodological approach to model climate and land-use change impacts on faecal contamination in rivers taking into account the large uncertainty affecting both observations and model results. 


\section{Acknowledgements}

We are grateful to the Department for Environment, Food \& Rural Affairs (DEFRA) and the Natural Environment Research Council (NERC) for funding the Integrated Modelling Project (contract NEC05158) and to the MaRIUS project (Managing the Risks, Impacts and Uncertainties of droughts and water Scarcity), also funded by NERC, under the UK Droughts and Water Scarcity Programme (Grant NE/L010364/1). FIB data were collected within the framework of the Turf2Surf project funded by NERC, under the Macronutrient Cycle Programme (Grants NE/J011991/1 and NE/J011908/1). The meteorological data (precipitation and temperature) were provided by the UK Met Office. The river flow data were provided by the National River Flow Archive. We would also like to thank the editor, the associate editor and two anonymous reviewers for their very useful comments.

\section{References}

Beven, K., 1989. Changing ideas in hydrology: the case of physically-based models. J. Hydrol. 105. doi:10.1016/0022-1694(89)90101-7

Bouvy, M., Briand, E., Boup, M.M., Got, P., Leboulanger, C., Bettarel, Y., Arfi, R., 2008. Effects of sewage discharges on microbial components in tropical coastal waters (Senegal, West Africa). Mar. Freshw. Res. 59, 614. doi:10.1071/MF07244

Buendia, C., Bussi, G., Tuset, J., Vericat, D., Sabater, S., Palau, A., Batalla, R.J., 2016. Effects of afforestation on runoff and sediment load in an upland Mediterranean catchment. Sci. Total Environ. 540, $144-157$. doi:10.1016/j.scitotenv.2015.07.005

Bussi, G., Dadson, S.J., Whitehead, P.G., Prudhomme, C., 2016a. Modelling the future impacts of climate and land-use change on suspended sediment transport in the River Thames (UK). J. Hydrol. 542, 357-372. doi:10.1016/j.jhydrol.2016.09.010

Bussi, G., Janes, V., Whitehead, P.G., Dadson, S.J., Holman, I.P., 2017. Dynamic response of land use and river nutrient concentration to long-term climatic changes. Sci. Total Environ. 590-591, 818-831. doi:10.1016/j.scitotenv.2017.03.069

Bussi, G., Whitehead, P.G., Bowes, M.J., Read, D.S., Prudhomme, C., Dadson, S.J., 2016b. Impacts of climate change, land-use change and phosphorus reduction on phytoplankton in the River Thames (UK). Sci. Total Environ. 572, 1507-1519. doi:10.1016/j.scitotenv.2016.02.109

Chapra, S.C., 2013. Chapter 27. Pathogens, in: Surface Water-Quality Modelling, Waveland Pr Inc.

Chick, H., 1908. An Investigation of the Laws of Disinfection. J. Hyg. (Lond). 8, 92-158. doi:10.1017/S0022172400006987

Coffey, R., Dorai-Raj, S., O'Flaherty, V., Cormican, M., Cummins, E., 2013. Modeling of Pathogen Indicator Organisms in a Small-Scale Agricultural Catchment Using SWAT. Hum. Ecol. Risk Assess. An Int. J. 19, 232-253. doi:10.1080/10807039.2012.701983

Conwy County Borough, 2017. Monitoring the economy Research bulletin Issue 25 February 2017 Corporate Research and Information Unit.

Copeland, C.C., Beers, B.B., Thompson, M.R., Fitzgerald, R.P., Barrett, L.J., Sevilleja, J.E., Alencar, S., Lima, A.A.M., Guerrant, R.L., 2009. Faecal contamination of drinking water in a Brazilian shanty town: importance of household storage and new human faecal marker testing. J. Water Health 7, 324. doi:10.2166/wh.2009.081

Couture, R.M., Tominaga, K., Starrfelt, J., Moe, S.J., Kaste, Ø., Wright, R.F., 2014. Modelling phosphorus loading and algal blooms in a Nordic agricultural catchment-lake system under changing land-use and climate. Environ. Sci. Process. Impacts 16, 1588-99. doi:10.1039/c3em00630a

de Brauwere, A., Ouattara, N.K., Servais, P., 2014. Modeling fecal indicator bacteria concentrations in natural surface waters: a review. Crit. Rev. Environ. Sci. Technol. 140225123512007. doi:10.1080/10643389.2013.829978

de Wit, H.A., Ledesma, J.L.J., Futter, M.N., 2016. Aquatic DOC export from subarctic Atlantic blanket bog in Norway is controlled by seasalt deposition, temperature and precipitation. Biogeochemistry 127, 305-321. doi:10.1007/s10533-016-0182-z 
Delpla, I., Jung, A.V., Baures, E., Clement, M., Thomas, O., 2009. Impacts of climate change on surface water quality in relation to drinking water production. Environ. Int. 35, 1225-1233. doi:10.1016/j.envint.2009.07.001

Durand, P., 2004. Simulating nitrogen budgets in complex farming systems using INCA: calibration and scenario analyses for the Kervidy catchment (W. France). Hydrol. Earth Syst. Sci. 8, 793-802. doi:10.5194/hess-8793-2004

Emmett, B.A., Cooper, D., Smart, S., Jackson, B., Thomas, A., Cosby, B.J., Evans, C., Glanville, H., McDonald, J.E., Malham, S.K., Marshall, M., Jarvis, S., Rajko-Nenow, P., Webb, G.P., Ward, S., Rowe, E., Jones, L., Vanbergen, A.J., Keith, A., Carter, H., Pereira, M.G., Hughes, S., Lebron, I., Wade, A., Jones, D.L., 2016. Spatial patterns and environmental constraints on ecosystem services at a catchment scale. Sci. Total Environ. doi:10.1016/j.scitotenv.2016.04.004

Ferguson, C.M., Croke, B.F.W., Beatson, P.J., Ashbolt, N.J., Deere, D.A., 2007. Development of a processbased model to predict pathogen budgets for the Sydney drinking water catchment. J. Water Health 5, 187-208. doi:10.2166/wh.2007.013

Futter, M.N., Butterfield, D., Cosby, B.J., Dillon, P.J., Wade, A.J., Whitehead, P.G., 2007. Modeling the mechanisms that control in-stream dissolved organic carbon dynamics in upland and forested catchments. Water Resour. Res. 43. doi:10.1029/2006WR004960

Futter, M.N., Erlandsson, M.A., Butterfield, D., Whitehead, P.G., Oni, S.K., Wade, A.J., 2014. PERSiST: a flexible rainfall-runoff modelling toolkit for use with the INCA family of models. Hydrol. Earth Syst. Sci. 18, 855-873. doi:10.5194/hess-18-855-2014

Garzio-Hadzick, A., Shelton, D.R., Hill, R.L., Pachepsky, Y.A., Guber, A.K., Rowland, R., 2010. Survival of manure-borne E. coli in streambed sediment: Effects of temperature and sediment properties. Water Res. 44, 2753-2762. doi:10.1016/j.watres.2010.02.011

Hernández-Delgado, E.A., Sandoz, B., Bonkosky, M., Norat-Ramírez, J., Mattei, H., 2008. Impacts of non-point source sewage pollution on Elkhorn coral, Acropora palmata (Lamarck), assemblages of the southwestern Puerto Rico shelf, in: Proceedings of the 11th International Coral Reef Symposium, Ft. Lauderdale, Florida, 7-11 July 2008 Session Number 18. pp. 747-751.

Hunter, P.R., 2003. Climate change and waterborne and vector-borne disease. J. Appl. Microbiol. 94, 37-46. doi:10.1046/j.1365-2672.94.s1.5.x

ludicello, J.., Chin, D.., 2015. In-Stream Bacteria Modeling as a Function of the Hydrologic State of a Watershed. J. Environ. Eng. 141. doi:http://dx.doi.org/10.1061/(ASCE)EE.1943-7870.0000879\#sthash.CcXEB954.dpuf

Jackson-Blake, L.A., Starrfelt, J., 2015. Do higher data frequency and Bayesian auto-calibration lead to better model calibration? Insights from an application of INCA-P, a process-based river phosphorus model. J. Hydrol. 527, 641-655. doi:10.1016/j.jhydrol.2015.05.001

Kay, D., Crowther, J., Stapleton, C.M., Wyer, M.D., Fewtrell, L., Anthony, S., Bradford, M., Edwards, A., Francis, C.A., Hopkins, M., Kay, C., McDonald, A.T., Watkins, J., Wilkinson, J., 2008. Faecal indicator organism concentrations and catchment export coefficients in the UK. Water Res. 42, 2649-2661. doi:10.1016/j.watres.2008.01.017

Kay, D., Watkins, J., Francis, C.A., Wyn-Jones, A.P., Stapleton, C.M., Fewtrell, L., Wyer, M.D., Drury, D., 2007. The microbiological quality of seven large commercial private water supplies in the United Kingdom. J. Water Health 5, 523-538. doi:10.2166/wh.2007.042

Lázár, A.N., Butterfield, D., Futter, M.N., Rankinen, K., Thouvenot-Korppoo, M., Jarritt, N.P., Lawrence, D.S.L., Wade, A.J., Whitehead, P.G., 2010. An assessment of the fine sediment dynamics in an upland river system: INCA-Sed modifications and implications for fisheries. Sci. Total Environ. 408, 2555-2566. doi:10.1016/j.scitotenv.2010.02.030

Lu, Q., Futter, M.N., Nizzetto, L., Bussi, G., Jürgens, M.D., Whitehead, P.., 2016. Fate and Transport of Polychlorinated Biphenyls (PCBs) in the River Thames Catchment - Insights from a Coupled Multimedia Fate and Hydrobiogeochemical Transport Model. Sci. Total Environ. 572, 1461-1470. doi:10.1016/j.scitotenv.2016.03.029

Malham, S.K., Rajko-Nenow, P., Howlett, E., Tuson, K.E., Perkins, T.L., Pallett, D.W., Wang, H., Jago, C.F., Jones, D.L., McDonald, J.E., 2014. The interaction of human microbial pathogens, particulate material and nutrients in estuarine environments and their impacts on recreational and shellfish waters. Environ. Sci. Process. Impacts 16, 2145-55. doi:10.1039/c4em00031e

McGrane, S.J., Tetzlaff, D., Soulsby, C., 2014. Application of a linear regression model to assess the influence of urbanised areas and grazing pastures on the microbiological quality of rural streams. Environ. Monit. Assess. 186, 7141-7155. doi:10.1007/s10661-014-3916-1

Moriasi, D.N., Arnold, J.G., Van Liew, M.W., Bingner, R.L., Harme, R.D., Veith, T.L., 2007. Model evaluation guidelines for systematic quantification of accuracy in watershed simulations. Trans. ASAE 50, 885-900.

Muirhead, R.W., Elliott, A.H., Monaghan, R.M., 2011. A model framework to assess the effect of dairy farms and wild fowl on microbial water quality during base-flow conditions. Water Res. 45, 2863-2874. doi:10.1016/j.watres.2011.03.001

Murphy, J.M., Sexton, D.M.H., Jenkins, G.J., Booth, B.B.B., Brown, C.C., Clark, R.T., Collins, M., Harris, G.R., Kendon, E.J., Betts, R.A., Brown, S.J., Humphrey, K.A., McCarthy, M.P., McDonald, R.E., Stephens, A., Wallace, C., Warren, R., Wilby, R.L., Wood, R.A., 2009. UK Climate Projections Science Report: Climate Change Projections, Met Office Hadley Centre, Exeter.

Nakicenovic, N., Grübler, A., Gaffin, S., Jung, T.T., Kram, T., Morita, T., Pitcher, H., Riahi, K., Schlesinger, M., Shukla, P.R., van Vuuren, D., Davis, G., Michaelis, L., Swart, R., Victor, N., 2003. IPCC SRES Revisited: A 
Response. Energy Environ. 14, 187-214. doi:10.1260/095830503765184592

Nash, J.E., Sutcliffe, J.V., 1970. River flow forecastin through conceptual models - Part 1 - A discussion of principles. J. Hydrol. 10, 282-290. doi:10.1016/0022-1694(70)90255-6

Nizzetto, L., Bussi, G., Futter, M.N., Butterfield, D., Whitehead, P.G., 2016. A theoretical assessment of microplastic transport in river catchments and their retention by soils and river sediments. Environ. Sci. Process. Impacts 18, 1050-1059. doi:10.1039/C6EM00206D

Oni, S.K., Futter, M.N., Buttle, J., Dillon, P.J., 2015. Hydrological footprints of urban developments in the Lake Simcoe watershed, Canada: a combined paired-catchment and change detection modelling approach. Hydrol. Process. 29, 1829-1843. doi:10.1002/hyp.10290

Oni, S.K., Futter, M.N., Teutschbein, C., Laudon, H., 2014. Cross-scale ensemble projections of dissolved organic carbon dynamics in boreal forest streams. Clim. Dyn. 42, 2305-2321. doi:10.1007/s00382-0142124-6

Perkins, T.L., Clements, K., Baas, J.H., Jago, C.F., Jones, D.L., Malham, S.K., McDonald, J.E., 2014. Sediment composition influences spatial variation in the abundance of human pathogen indicator bacteria within an estuarine environment. PLoS One 9. doi:10.1371/journal.pone.0112951

Perkins, T.L., Perrow, K., Rajko-Nenow, P., Jago, C.F., Jones, D.L., Malham, S.K., McDonald, J.E., 2016. Decay rates of faecal indicator bacteria from sewage and ovine faeces in brackish and freshwater microcosms with contrasting suspended particulate matter concentrations. Sci. Total Environ. doi:10.1016/j.scitotenv.2016.03.076

Prosser, H., Pagella, T., Durance, I., 2014. Upland Scenarios: what will the future look like? Duress Project report card. http://www.nerc-bess.net/documents/DURESS-Upland-Scenarios-Report.pdf.

Prudhomme, C., Dadson, S.J., Morris, D., Williamson, J., Goodsell, G., Crooks, S., Boelee, L., Davies, H., Buys, G., Lafon, T., Watts, G., 2012. Future Flows Climate: an ensemble of 1-km climate change projections for hydrological application in Great Britain. Earth Syst. Sci. Data 4, 143-148. doi:10.5194/essd-4-143-2012

Prudhomme, C., Haxton, T., Crooks, S., Jackson, C., Barkwith, A., Williamson, J., Kelvin, J., Mackay, J., Wang, L., Young, A., Watts, G., 2013. Future Flows Hydrology: an ensemble of daily river flow and monthly groundwater levels for use for climate change impact assessment across Great Britain. Earth Syst. Sci. Data 5, 101-107. doi:10.5194/essd-5-101-2013

Rankinen, K., Butterfield, D., Faneca-Sánchez, M., Grizzetti, B., Whitehead, P.G., Pitkänen, T., Uusi-Kämppä, J., Leckie, H., 2016. The INCA-Pathogens model: An application to the Loimijoki River basin in Finland. Sci. Total Environ. 1-11. doi:10.1016/j.scitotenv.2016.05.043

Rose, J.B., Epstein, P.R., Lipp, E.K., Sherman, B.H., Bernard, S.M., Patz, J.A., 2001. Climate variability and change in the United States: potential impacts on water- and foodborne diseases caused by microbiologic agents. Environ. Health Perspect. 109, 211-221.

Smith, G., Beare, M., Boyd, M., Downs, T., Gregory, M., Morton, D., Brown, N., Thomson, A.G., 2007. UK Land Cover Map Production Through the Generalisation of OS MasterMap®. Cartogr. J. 44, 276-283. doi:10.1179/000870407X241827

Spear, R.C., Hornberger, G.M., 1980. Eutrophication in peel inlet-II. Identification of critical uncertainties via generalized sensitivity analysis. Water Res. 14, 43-49. doi:10.1016/0043-1354(80)90040-8

Statistics for Wales, 2015. Welsh Agricultural Statistics 2015.

Tong, S.T.Y., Chen, W., 2002. Modeling the relationship between land use and surface water quality. J. Environ. Manage. 66, 377-393. doi:10.1006/jema.2002.0593

Wade, A.J., Durand, P., Beaujouan, V., Wessel, W.., Raat, K.J., Whitehead, P.G., Butterfield, D., Rankinen, K., Lepisto, A., 2002a. A nitrogen model for European catchments: INCA, new model structure and equations. Hydrol. Earth Syst. Sci. 6, 559-582. doi:10.5194/hess-6-559-2002

Wade, A.J., Whitehead, P.G., Butterfield, D., 2002b. The Integrated Catchments model of Phosphorus dynamics (INCA-P), a new approach for multiple source assessment in heterogeneous river systems: model structure and equations. Hydrol. Earth Syst. Sci. doi:10.5194/hess-6-583-2002

Whitehead, P.G., Bussi, G., Bowes, M.J., Read, D.S., Hutchins, M.G., Elliott, J.A., Dadson, S.J., 2015a. Dynamic modelling of multiple phytoplankton groups in rivers with an application to the Thames river system in the UK. Environ. Model. Softw. 74, 75-91. doi:10.1016/j.envsoft.2015.09.010

Whitehead, P.G., Leckie, H., Rankinen, K., Butterfield, D., Futter, M.N., Bussi, G., 2016. An INCA model for pathogens in rivers and catchments: Model structure, sensitivity analysis and application to the River Thames catchment, UK. Sci. Total Environ. 572, 1601-1610. doi:10.1016/j.scitotenv.2016.01.128

Whitehead, P.G., Sarkar, S., Jin, L., Futter, M.N., Caesar, J., Barbour, E., Butterfield, D., Sinha, R., Nicholls, R., Hutton, C., Leckie, H.D., 2015b. Dynamic modeling of the Ganga river system: impacts of future climate and socio-economic change on flows and nitrogen fluxes in India and Bangladesh. Environ. Sci. Process. Impacts 17, 1082-1097. doi:10.1039/C4EM00616J

Whitehead, P.G., Wilby, R.L., Battarbee, R.W., Kernan, M., Wade, A.J., 2009. A review of the potential impacts of climate change on surface water quality. Hydrol. Sci. Journal/Journal des Sci. Hydrol. 54, 101-123. doi:10.1623/hysj.54.1.101

Whitehead, P.G., Wilson, E., Butterfield, D., 1998a. A semi-distributed integrated nitrogen model for multiple source assessment in catchments (INCA): Part I - model structure and process equations. Sci. Total Environ. 210-211, 547-558. doi:10.1016/S0048-9697(98)00037-0

Whitehead, P.G., Wilson, E., Butterfield, D., Seed, K., 1998b. A semi-distributed integrated flow and nitrogen model for multiple source assessment in catchments (INCA): Part II - application to large river basins in south Wales and eastern England. Sci. Total Environ. 210-211, 559-583. doi:10.1016/S0048- 
9697(98)00038-2

WHO, 2003. Guidelines for safe recreational water environments. Volume 1, Coastal and fresh waters. World Health Organization, Geneva. 


\section{Tables}

Table 1. Summary of the data collected.

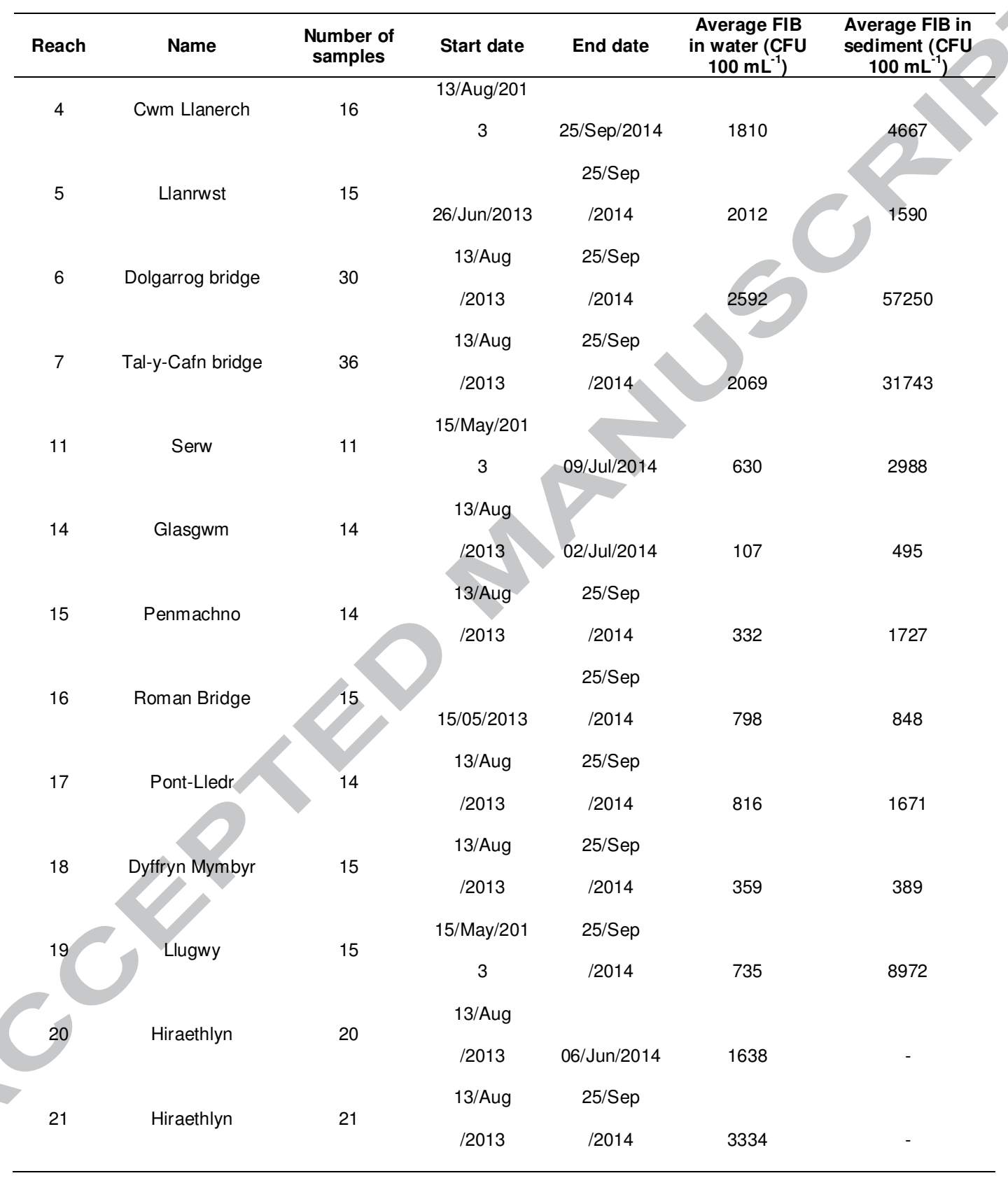


Table 2. Raingauges used in the present study.

\begin{tabular}{ccccc}
\hline $\begin{array}{c}\text { Met Office } \\
\text { ID }\end{array}$ & Name & Lat $\left({ }^{\circ}\right)$ & Lon $\left({ }^{\circ}\right)$ & $\begin{array}{c}\text { Elevation } \\
(\mathbf{m} \text { AOD })\end{array}$ \\
\hline 1148 & BETWS-Y-COED & 53.10 & -3.79 & 22 \\
1171 & CAPEL CURIG NO 3 & 53.09 & -3.94 & 216 \\
11488 & YSBYTY-IFAN W WKS & 52.99 & -3.77 & 392 \\
11494 & VOELAS HALL & 53.05 & -3.71 & 195 \\
17177 & LOUGHGALL NO 2 & 54.41 & -6.59 & 37 \\
19267 & PADOG & 53.05 & -3.75 & 220 \\
56440 & LLANRWST S WKS & 53.14 & -3.80 & 9 \\
57091 & CALEDON: MAIN STREET & 54.35 & -6.84 & 38 \\
\hline
\end{tabular}


Table 3. INCA model sub-catchments and reaches and their correspondent land uses under the baseline scenario. Sub-catchment 6, 78 and 9 are not shown as they are tidal sub-catchments

\begin{tabular}{|c|c|c|c|c|c|c|c|c|c|}
\hline $\begin{array}{l}\text { Reac } \\
\text { h ID }\end{array}$ & Stream & $\begin{array}{l}\text { Area } \\
\left(\mathrm{km}^{2}\right)\end{array}$ & $\begin{array}{c}\text { Reach } \\
\text { length } \\
\text { (m) }\end{array}$ & $\begin{array}{c}\text { Urban } \\
\text { land (\%) }\end{array}$ & $\begin{array}{c}\text { Forest } \\
\text { land (\%) }\end{array}$ & $\begin{array}{c}\text { Natural } \\
\text { grassland } \\
(\%)\end{array}$ & $\begin{array}{c}\text { Improved } \\
\text { grassland } \\
(\%)\end{array}$ & $\begin{array}{c}\text { Shrubland } \\
(\%)\end{array}$ & $\begin{array}{c}\text { Arable } \\
\text { land (\%) }\end{array}$ \\
\hline 1 & Conwy & 23.48 & 5400 & 0 & 2 & 34 & 8 & 53 & 3 \\
\hline 2 & Conwy & 19.89 & 1350 & 0 & 3 & 35 & 58 & 0 & \\
\hline 3 & Conwy & 12.59 & 3640 & 2 & 39 & 28 & 26 & 3 & 2 \\
\hline 4 & Conwy & 4.52 & 1740 & 4 & 67 & 5 & 22 & 1 & 1 \\
\hline 5 & Conwy & 24.09 & 3230 & 2 & 17 & 15 & 65 & 0 & 1 \\
\hline 10 & Conwy & 5.73 & 1580 & 7 & 0 & 4 & 0 & 89 & 0 \\
\hline 11 & Conwy & 6.59 & 3270 & 0 & 0 & 24 & 0 & 76 & 0 \\
\hline 12 & Merddwr & 42.50 & 6580 & 0 & 2 & 50 & 37 & 6 & 5 \\
\hline 13 & Conwy & 37.91 & 4520 & 0 & 3 & 63 & 26 & 6 & 2 \\
\hline 14 & Machno & 2.68 & 1370 & 0 & 63 & 25 & 0 & 12 & 0 \\
\hline 15 & Machno & 4.49 & 2840 & 0 & 64 & 18 & 9 & 9 & 0 \\
\hline 16 & Machno & 33.65 & 3050 & 2 & & 41 & 13 & 24 & 0 \\
\hline 17 & Lledr & 72.00 & 15300 & 5 & 29 & 50 & 3 & 12 & 1 \\
\hline 18 & Llugwy & 16.28 & 4490 & 9 & 0 & 66 & 0 & 25 & 0 \\
\hline 19 & Llugwy & 60.12 & 16170 & 6 & 22 & 57 & 3 & 12 & 0 \\
\hline 20 & Hiraethlyn & 7.66 & 4440 & 0 & 10 & 10 & 77 & 1 & 2 \\
\hline 21 & Hiraethlyn & 12.77 & 3100 & 0 & 9 & 20 & 70 & 0 & 1 \\
\hline
\end{tabular}


Table 4. Model calibration results.

\begin{tabular}{ccccc}
\hline Reach & Name & Flow R & Water FIB R & Sediment FIB R \\
\hline 4 & Cwm Llanerch & $0.49-0.61$ & $0.21-0.44$ & $0.30-0.89$ \\
5 & Llanrwst & - & $0.12-0.64$ & $0.00-0.20$ \\
11 & Serw & - & $0.00-0.35$ & $0.00-0.03$ \\
14 & Glasgwm & - & $0.01-0.28$ & $0.57-0.67$ \\
15 & Penmachno & - & $0.00-0.27$ & $0.01-0.36$ \\
16 & Roman Bridge & - & $0.10-0.48$ & $0.12-0.86$ \\
17 & Pont-Lledr & $0.34-0.41$ & $0.00-0.26$ & $0.00-0.23$ \\
18 & Dyffryn Mymbyr & - & $0.10-0.75$ & $0.02-0.10$ \\
19 & Llugwy & - & $0.00-0.21$ & $0.00-0.33$ \\
20 & Hiraethlyn & - & $0.15-0.53$ & - \\
21 & Hiraethlyn & - & $0.15-0.38$ & - \\
\hline
\end{tabular}


Table 5. Combined impact of climate and land-use change on water faecal indicator bacteria for different time horizons. The average change is represented, as well as the $5 / 95$ percentile range, according to the model results.

\begin{tabular}{|c|c|c|c|c|}
\hline & & \multicolumn{3}{|c|}{$\%$ change in median FIB } \\
\hline $\begin{array}{c}\text { Land use } \\
\text { scenario }\end{array}$ & $\begin{array}{c}\text { Time } \\
\text { horizon }\end{array}$ & Reach 4 & Reach 18 & Reach 16 \\
\hline Baseline & $1960-1990$ & $0(0 / 0)$ & $0(0 / 0)$ & $0(0 / 0)$ \\
\hline Baseline & $2020-2050$ & $-18(-20 /-15)$ & $-15(-15 /-16)$ & $-18(-26 /-17)$ \\
\hline Baseline & $2060-2090$ & $-31(-28 /-25)$ & $-24(-21 /-25)$ & $-30(-40 /-27)$ \\
\hline Managed & $1960-1990$ & $-24(-5 /-36)$ & $-16(-11 /-17)$ & $-23(-19 /-24)$ \\
\hline Managed & $2020-2050$ & $-37(-26 /-46)$ & $-29(-23 /-30)$ & $-36(-38 /-36)$ \\
\hline Managed & $2060-2090$ & $-46(-30 /-53)$ & $-35(-28 /-38)$ & $-45(-49 /-44)$ \\
\hline Abandonment & $1960-1990$ & $-46(-25 /-59)$ & $-15(-3 /-16)$ & $-60(-50 /-65)$ \\
\hline Abandonment & $2020-2050$ & $-57(-38 /-71)$ & $-28(-23 /-29)$ & $-66(-58 /-71)$ \\
\hline Abandonment & $2060-2090$ & $-61(-41 /-73)$ & $-35(-28 /-37)$ & $-70(-64 /-75)$ \\
\hline Intensification & $1960-1990$ & $7(0 / 9)$ & $50(44 / 48)$ & $-1(-11 / 16)$ \\
\hline Intensification & $2020-2050$ & $-9(-21 / 4)$ & $24(9 / 27)$ & $-18(-33 /-3)$ \\
\hline Intensification & $2060-2090$ & $-24(-29 /-8)$ & $8(-8 / 12)$ & $-31(-45 /-15)$ \\
\hline
\end{tabular}




\section{Figure captions}

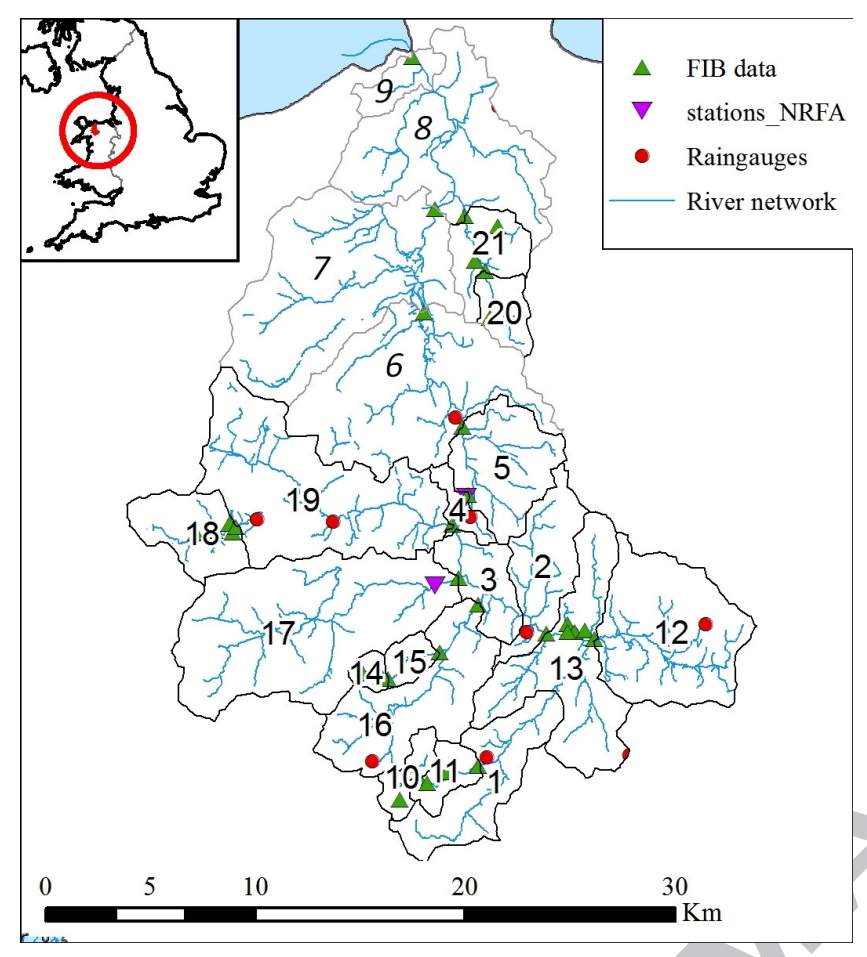

Figure 1 - River Conwy location, sub-catchments, stream gauges, raingauges and FIB data collection points. The catchments with grey boundaries are affected by tidal water, and therefore the INCA model results do not apply (the INCA model is a freshwater quality model), but they are indicated anyway because they are present in the model structure. The blue line represents the river network, including both the non-tidal and tidal sections. 


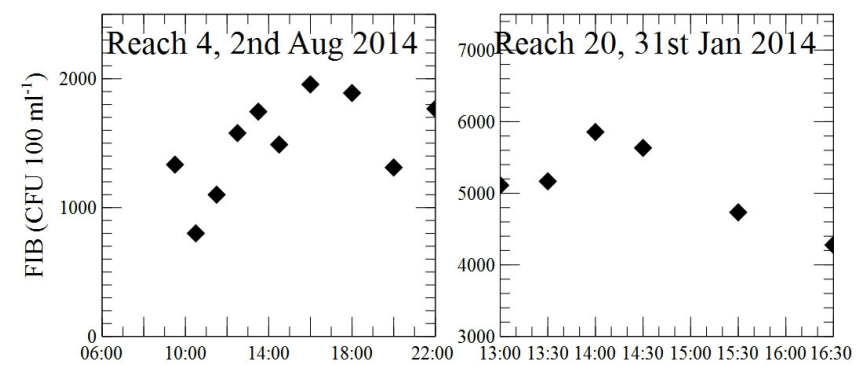

Figure 2 - Sub-daily variation of the FIB concentration of the River Conwy at Cwm Llanerch (reach 4) and of a tributary at Hiraethlyn (reach 20). 

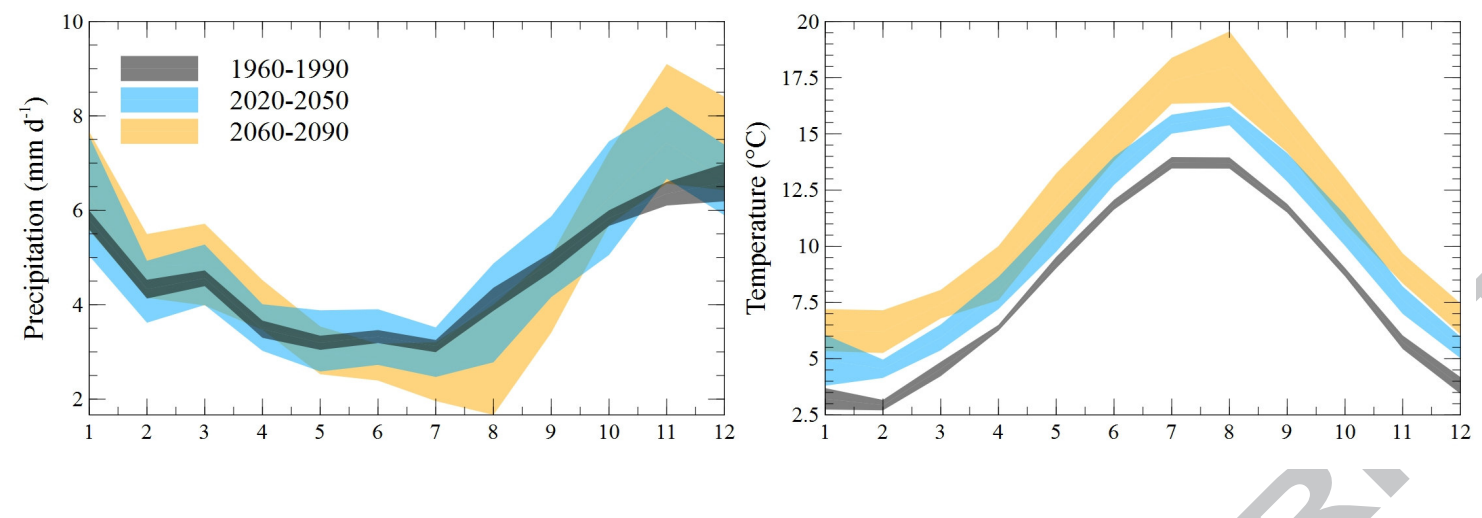

Figure 3 - Precipitation and temperature for the River Conwy catchment for different time horizons.

The ranges of variations were obtained from the 11 members of the FFC. 
Arable land Forest land Grassland Imp. grassland

a)
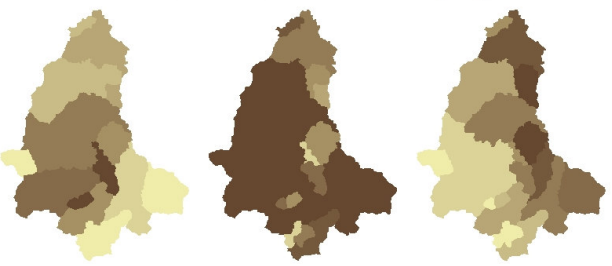

b)
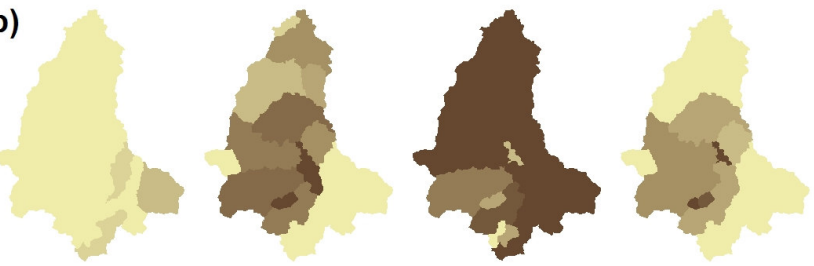

c)
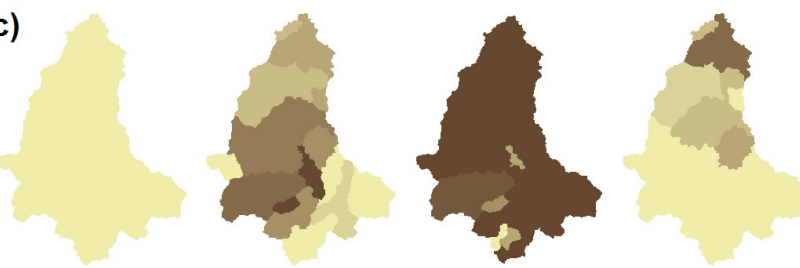

d)

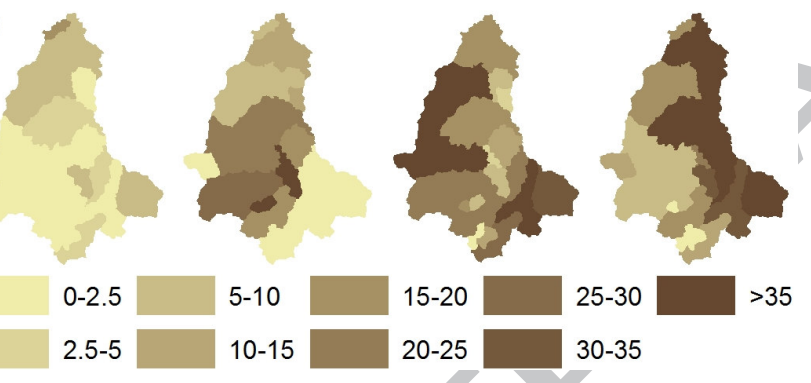

Figure 4 - Land-use change scenarios considered in this study (Prosser et al., 2014): a) baseline, b) managed ecosystems, c) abandonment, d) agricultural intensification. The values are in percentage. 


\section{ACCEPTED MANUSCRIPT}
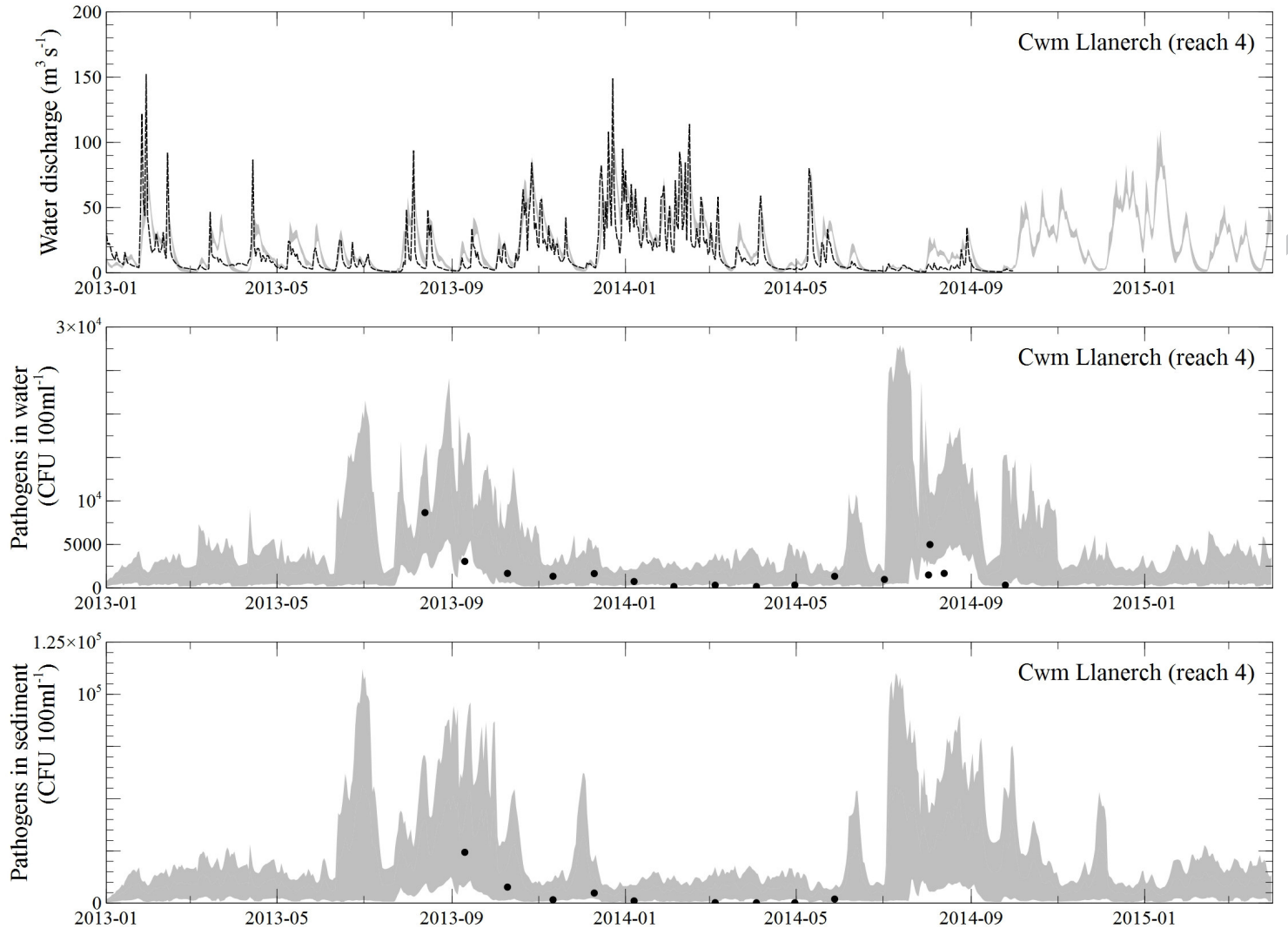

Figure 5 - Model calibration results (reach $4-$ Cwm Llanerch). The grey area represents the results of the behavioural models and the black line/black dots the observed values. 


\section{ACCEPTED MANUSCRIPT}
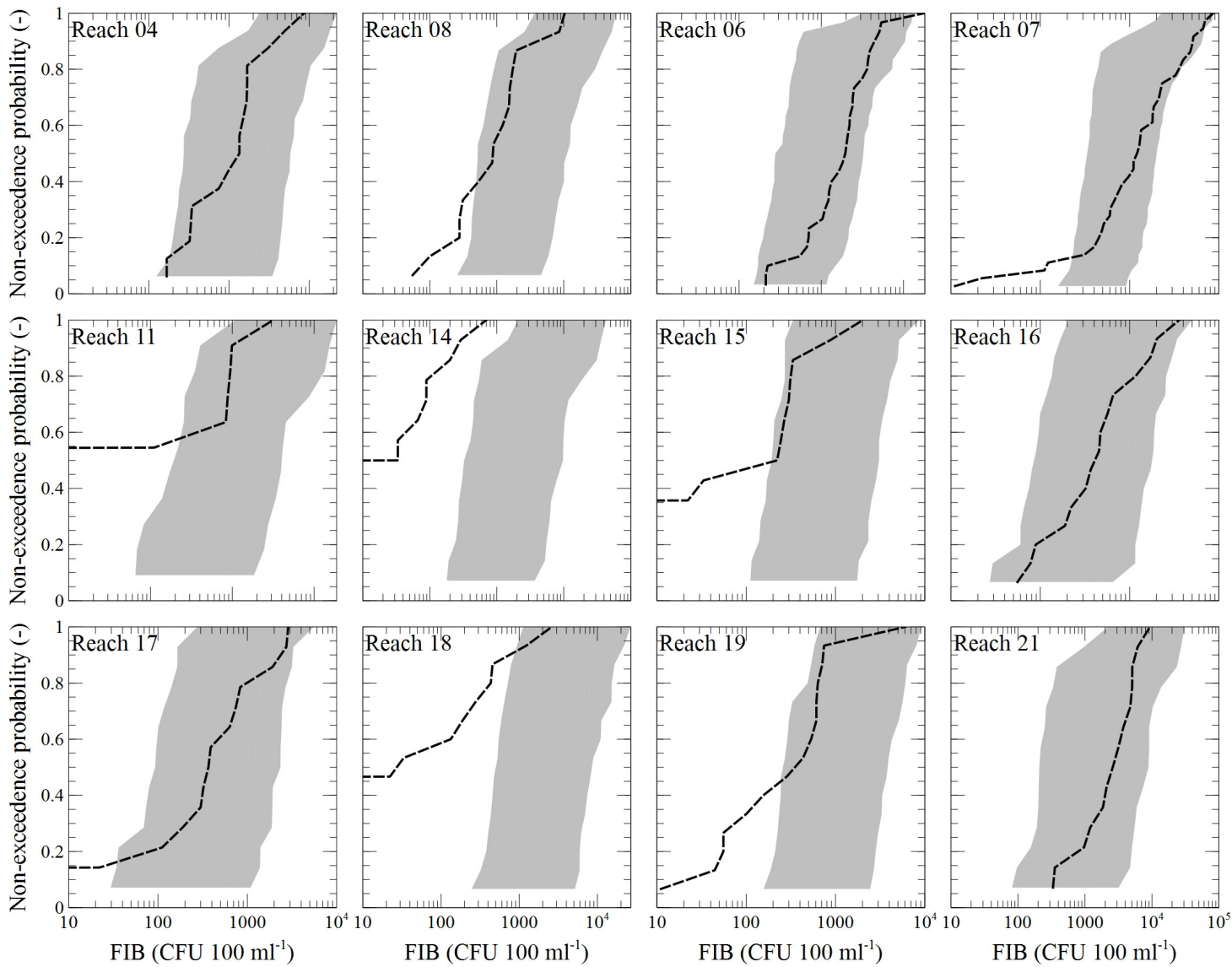

Figure 6 - Model validation (empirical cumulative distribution functions of faecal indicator bacteria).

The grey areas represent the results of the behavioural models and the black lines the distribution function of the observed values. 

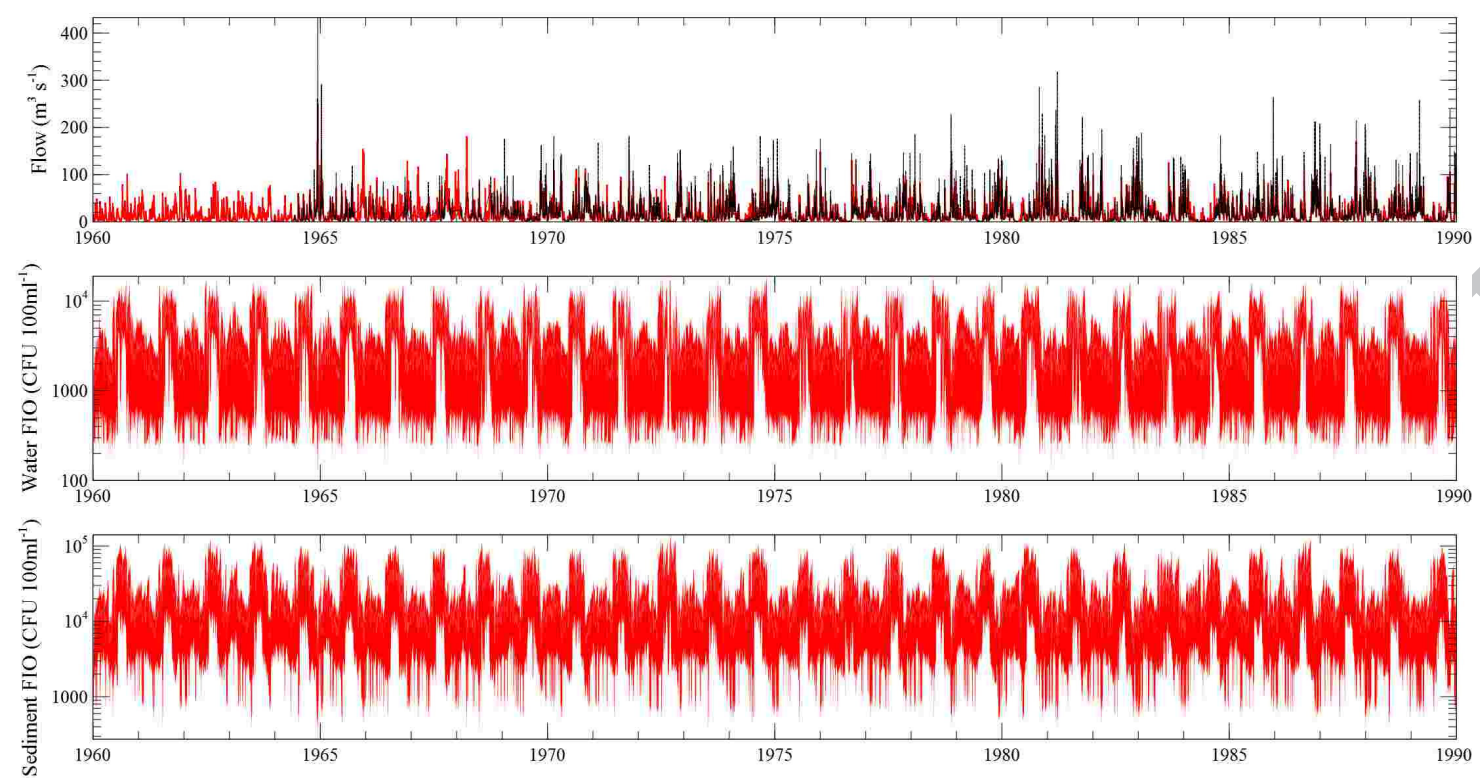

Figure 7 - Model validation (time series of flow, water FIO and sediment FIO) from 1960 to 1990. 

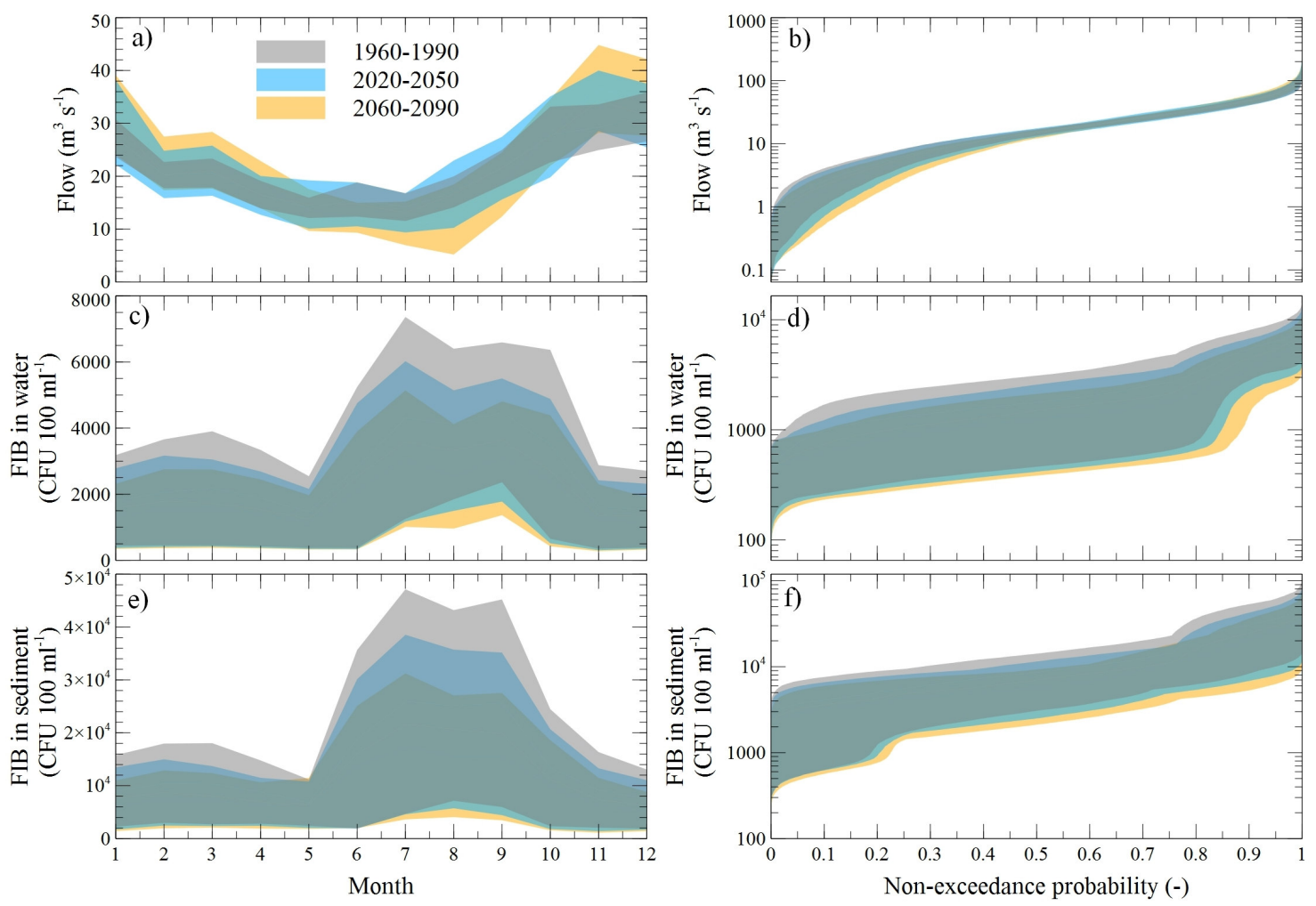

Figure 8 - Flow, FIB in water and FIB in sediment (monthly averages - a, c and e, and duration curve/cumulative distribution function $-b, d$ and f) (reach 4) under climate change for different time horizons. 


\section{ACCEPTED MANUSCRIPT}

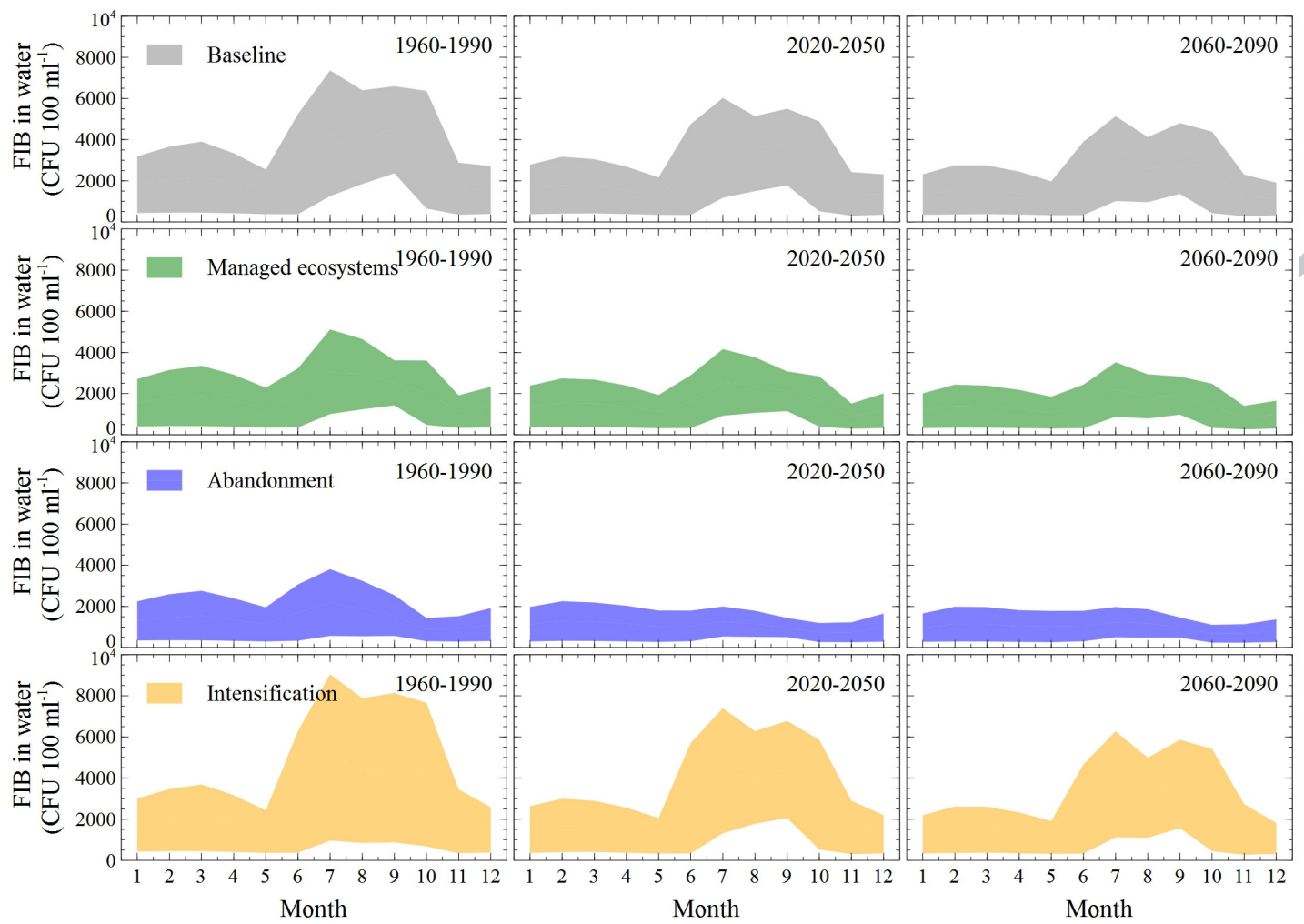

Figure 9 - Combined impact of climate and land-use change on water faecal indicator bacteria (reach 4) for different time horizons. 


\section{Climate and land-use change impact on faecal indicator bacteria in a temperate maritime catchment (the River Conwy, Wales)}

Gianbattista Bussi ${ }^{1 *}$, Paul G. Whitehead ${ }^{1}$, Amy R.C. Thomas ${ }^{2}$, Dario Masante ${ }^{2}$, Laurence Jones ${ }^{2}$, B. Jack Cosby ${ }^{2}$, Bridget A. Emmett ${ }^{2}$, Shelagh K. Malham ${ }^{3}$, Christel Prudhomme, ${ }^{4,5,6}$, Havard Prosser ${ }^{7}$ 1 - School of Geography and the Environment, University of Oxford, South Parks Road, Oxford, OX1 3QY (UK)

2 - Centre for Ecology \& Hydrology (CEH), Environment Centre Wales, Deiniol Road, Bangor, Gwynedd, LL57 2UW (UK)

3 - School of Ocean Sciences, Bangor University, Menai Bridge, Anglesey, LL59 5AB (UK)

4 - Centre for Ecology and Hydrology (CEH), Benson Lane, Crowmarsh Gifford, Wallingford, OX10 8BB (UK)

5 - Department of Geography, Loughborough University, Loughborough, LE11 3TU (UK)

6 - European Centre for Medium-Range Weather Forecasts, Shinfield Park, Reading, RG2 9AX (UK)

7 Cardiff School of Biosciences, Cardiff University, Museum Avenue, Cardiff, CF10 3AX (UK)

*Corresponding author: gianbattista.bussi@ouce.ox.ac.uk

\section{Highlights}

Faecal contamination is a serious threat to human use of water

The River Conwy in Wales shows high contents of faecal indicator bacteria

The INCA-Pathogens model was used to assess climate and land-use change impacts 
Faecal contamination is expected to decrease in summer due to climate change

Land-use management is a key control to reduce pathogen pollution 